\title{
Industrial Cluster: An Approach for Rural Development in North East India
}

\author{
Rinku Das and Ashim Kumar Das
}

\begin{abstract}
The industrial cluster is not a new phenomenon. It has evolved in a process after passing through numbers of economic theory developed starting from Location Theory in 1826 by Ven Thunen, Marshal's Industrial District Theory (1920), Max Weber's Industrial Complex Theory (1950) and Industrial Cluster Theory by Michal Porter (1990). The cluster concept has attracted many policy maker, academicians and researchers as a vital strategy for rural development (economic and industrial). Today, the developed and developing economy implementing cluster concept as an instrument for the development of rural small and households industries and also for the development of communities related to these industries. Generally the cluster concept suggests a change in the units of analysis from isolated firms to a network of firms, which have an advantage of effective local knowledge up gradation, skill development, empowerment of local community, caste people and innovation etc. In North East thousands of small and rural households industries are operating among village communities and different caste. These industries are based on local resources and traditional skills available with the rural people of NE (e.g. cane and bamboo, pottery industry, silk cloth making, brass metal and Bell metal, Terracotta etc). Rural households industries have been acting as a sustainable livelihood for the rural people in NE. In spite of various attempts by the central and state government these rural households industries in this region are not performing up to the mark. To give new life to the existing small and rural industries the government (Central) has adopted the policy of cluster development. This will provide competitive advantage to the firm in three different ways, namely productivity, innovation, and formation of new business firms. This paper will highlight on the cluster development initiatives in NE and their implication on rural economic and industrial development.
\end{abstract}

Index Terms - industrial cluster, productivity, innovation

\section{INTRODUCTION}

Historically Indian economy is comprises two sectors rural and urban. The rural India plays a very important role in deciding economic development as 70 percent of Indian population lives in rural areas. The major source of earnings of rural population comes from agricultural. Other then agriculture, rural economy also depends on non-agricultural sub-sector consist of several economic activities such as cottage and village industries, khadi, handloom, handicrafts, trading of general goods, small shops, petty traders and service such as - transportation, communication, banking,

Manuscript received February 27, 2011.

Rinku Das, Research Scholar,Department of Humanities and Social Sciences, NIT Silchar, Assam, India (email:rinku.nil@gmail.com ).

Ashim Kumar Das, Assistant Professor, Department of Humanities and Social Sciences, NIT Silchar, Assam, India (email:ashimkd_nits@rediffmail.com). input supply and marketing of farm and non-farm producers (Singh, 2009). Many recent research studies have shown that the population dependency and engagement in agricultural sector in India has been decreasing since last few years. It is evident from the fact that the agricultural contribution has come down to only 18 percent of country's GDP. The non-availability of cultivable land (huge pressure of increasing population, joint family's land division system etc.), low irrigation facilities, lack of technological up-gradation in production, miss management of land, recurring flood, etc have forcefully shifted rural people from agriculture to the non-agricultural activities. If we take the case of north eastern states, the agriculture is underdeveloped and subsistence in nature, low industrialization of the region and under development of basic infrastructure has compled the rural population to take up some economic activities based on their natural/ traditional skill. The small business plays a vital role in country's economy. It is estimated that SME (small and medium enterprises) sectors contributes 40 percent of industrial production, 35 percent of manufacturing exports and employment about 24 million people in over 13 million units. The numbers of employment in each unit has increased from 4.48 (2001-02) to 6.24 (2006-07) per unit. These industries are particularly food processing, chemical and pharmaceutical, sports goods, leather goods, plastic products, Handloom and Handicrafts etc.

In North Eastern Region (NER) of India, thousands of small households industries are operating in rural areas. These are all traditional households industries and operating by some communities and caste. The nature and characteristics of these small industries are-

- They are mostly labour pooling industries.

- The households industries in this region are basically caste and community base.

- The owners and employees are family member only.

- The industries are based on the locally available resources.

- These industries are basically run from their own house.

- They use less machinery and run with limited capital.

- Innovation in product, services and management, and information from outside sources is restricted by their limited capital, networks and skills.

The Government of India since independence, implementing various policies from time to time for the development of small and households industries. The policy includes setting up of - General Industrial Parks, Product Specific Industrial Parks such as Textiles, Food Processing, Information Technology etc., Industrial Estates, Special Economic Zones (SEZs) etc. However all these policy initiative by the central as well as the state government could 
not bring smile to the faces of artisan and households businesses of NER. The policies that have been taken till date for the development of small households industries in the rural areas could not touch the real sector. To overcome some of the limitations of government earlier policies, central government of India with support of UNIDO adopted the cluster development scheme in the year 1997, as a pilot project for the development of rural households industries. Generally cluster concept suggest connection and association of firms that are linked vertically and horizontally through their commonalities and complementariness in products, services, inputs, technologies, transportation, warehouse, and communication (porter, 1998). In many developing countries small and households industries are dominating the industrial clusters. In India, there are a numbers of industrial clusters which have evolved over a long period of time. These include artisanal, traditional, and modern industries. Most of the clusters were established naturally as traditional activities of local communities (NCEUS, 2009). The rural artisan cluster which is define as, 'geographically concentrated household units producing handicraft/handloom products, often belong to a traditional community, producing the long-established products for generations and the skill of centuries old'. The advantages of cluster base industries are:

- Clusters give opportunities to its members for work and grow in their host place.

- It attracts the new customer and public investment by providing high quality products and services, which benefits all area business.

- Cluster provides an opportunity to the firm for innovation (in their products and production, decision making process, management etc.), skill up gradation, entering into new local and regional market etc.

- Cluster provides an identity to the clustered firms and actors in the society and related market.

- It strengthens the bargaining power of the firms with the suppliers and buyers. This is required by an individual firm, but cannot be obtained due to their low economic of scale.

- Cluster helps the growth of regional economics through maximum utilization of local resources such as - human resources, forest and natural resources etc.

- The sustainable community and rural development has become possible only through the establishment of industrial cluster.

- The cluster helps in pro-poor growth in the country like India and particularly NER.

In NER the actual cluster development initiatives was taken into the year 2008 to bring a sustainable rural economic development by helping the traditional small households industries. According to the report of MSME at present about 305 SSI clusters are operating in NE. Among 263 are handloom and handicraft Micro industrial cluster. And many SSI cluster units are still in process to open in this region. A state wise report on Handloom, handicraft \& micro Enterprise cluster in NE has shown below-

The above Table (II) shows that unregistered and unorganised SSI clusters in NER plays a very important role. More than 63,000 nos. of units, employing 1, 60,000 labourer in this region is playing an alternative employment provider and earning opportunity to the rural people.

TABLE-I: STATE WiSE MicRo, HANDLOOM AND HANDiCRAFTS CLUSTER IN

\begin{tabular}{|c|c|c|c|}
\hline \multirow{2}{*}{ State } & $\begin{array}{c}\text { Micro cluster } \\
\text { registered/unre } \\
\text { gistered }\end{array}$ & Handloom & Handicrafts \\
\hline Assam & 46 & 23 & 23 \\
\hline Manipur & 20 & 26 & 11 \\
\hline Meghalaya & 10 & 16 & 3 \\
\hline Mizoram & 7 & 7 & 7 \\
\hline Nagaland & 4 & 15 & 7 \\
\hline Tripura & 2 & 24 & 4 \\
\hline Sikkim & - & 6 & 2 \\
\hline
\end{tabular}

Source: Foundation for MSME Clusters (2010).

TABLE-II: STATUS OF UNREGISTERED SSI CLUSTER IN NORTH EAST INDIA

\begin{tabular}{|c|c|c|c|}
\hline Name of state & $\begin{array}{c}\text { Nos. of } \\
\text { cluster }\end{array}$ & $\begin{array}{c}\text { Nos. of } \\
\text { units }\end{array}$ & Employment \\
\hline Nagaland & 3 & 3170 & 12734 \\
\hline Manipur & 13 & 18409 & 45347 \\
\hline Meghalaya & 3 & 4933 & 10336 \\
\hline Assam & 24 & 36683 & 90920 \\
\hline
\end{tabular}

Source: MSME report (2001-02).

\section{Role OF CLUSTER IN REGIONAL ECONOMIC GROWTH AND POVERTY ALLEVIATION}

The industrial cluster is not a new economic phenomenon. It was evolved a far long back, but its actual implementation started in the end of this nineteen century when globalization and liberalization took place in many developing countries. Presently, every developed and developing nation is taking cluster as a strategy for regional economic development. The ideas of cluster implementation for economic development vary between country to country and region to region. The more developed country like Italy, Japan etc. as they are more advance in technology, so their ideas for cluster approach is to go for international market penetration and enhancement of competitiveness etc. But the developing country likes India cluster approach is for - rural economic development, community development (through upliftment of traditional skills and knowledge etc), pro-poor growth, market development etc. According to a report (MSME foundation 2007), India have around 6000 micro enterprise clusters. Another database of UNIDO shows that there are more than 4000 artisanal and about 363 non- artisanal clusters in India. The overall picture in India shows a numerical domination of rural traditional artisanal clusters that are likely to be dominated entirely by small enterprises. These small artisanal clusters play an important role in regional economic development in India. Following are the economic benefits of cluster in India:

- Cluster creates a healthy co-relation between the central with state government, local institution/ organisation (NGO's, SHGs, clubs, societies etc.), international organisation (UNIDO, UNDP etc) and other educational institutions etc.

- The labour pooling nature of small industrial cluster can minimize the problem of unemployment for a less developed region. 
- The establishment of clusters in a particular region or area induces to set up other important business near by it.

- Cluster attracts the suppliers, customers and public investors in infrastructure by providing high quality products and services, which benefits all area business.

- The clustered firms through their co-operative work get the benefits of innovation in their products and production, services and management etc.

- The demand for labour raises and thereby the wage level of the labours than their earlier level.

- In cluster, the agglomeration benefit raises the efficiency of the small firms and makes it possible to access the markets through a division of labour.

- The cluster provides the small individual firms to specialize in specific tasks, access special skills and services and inputs.

- The agglomeration of small firms can lower the costs in accessing inputs, labour and information.

- The knowledge spillover in cluster make feasible to small firms to acquire new know-how, new products and new production techniques that could not be obtained through markets.

- Local co-operation, both individual firms and cluster institution can strengthen the ability of clustered actors to compete in markets, by sharing costs by engaging in join tasks such shared marketing and distribution.

- The rapid flow of capital, goods, people and ideas across boards, can help bring local actors in to global markets and enhance their income earnings opportunities.

The poverty is an age-old economic as well as a social phenomenon, dominating overall development of many developing countries in the world. The economic definition of poverty primarily based on the ability to purchases of goods and services that is on their income, consumption and on material possessions and assets (UNIDO, 2004). The government of India since its independence has been taking various policies and schemes to eradicate poverty from the societies. These are under the categories- self- employment programme, wage employment programme, public distribution system, other social oriented programmes such as- National Rural Employment Guarantee, Jawahar Rozgar Yojona, The Food for Work Programme, The Crash Scheme of Rural Employment etc. Nodoubtedly it has brought some positive outcomes in poverty reduction in certain states or regions of India. Most of these policies have their own limitation. Again, there is always a disparity between in rural and urban poverty reduction. According to the report of NSS (2004-05) the poverty in rural areas was 28.3 percent as against 25.7 percent in urban, and 7.5 percent for the country as a whole. In Indian the rural poverty is spreading among the small farmers, marginal and artisan sections. They are neither full time in agriculture nor in artisanal work. The government of India with UNIDO support started Cluster development approach as one of the policy initiative for development project in India to reduce poverty in the rural India and more particularly from the artisanal sectors. From the various empirical studies (Ministry of rural development India, UNIDO, MSME, Institute of Small Enterprise and Development etc.) it has found that, the industrial cluster has a positive impact on poverty reduction. Cluster and poverty, they are interrelated by two main dimension- income and employment.

There is a very less literature that we have on cluster base poverty reduction. Among this few UNIDO's study in 2004 'Industrial Cluster and Poverty Reduction', which says cluster and poverty are related in three distinct ways namelythrough cluster features, cluster process and cluster dynamics. The cluster feature indicates about the incipient or survival cluster that has direct impact on poverty. The more mature cluster has more impact on poverty by generating employment and income for relatively low wage workers and their households. The cluster process improves the ability of small firms to improve market access through externality gains and join action. This can raise income for those who work in clusters, raise their assets and capabilities and have a significant impact on lowering levels of poverty and social deprivation. The cluster dynamics which enhances the human capital improves technological capacities for firms and also enhance the capabilities for workers and small producers (UNIDO, 2004). There are numerous case studies on cluster which are directly related with the economic and socio-economic development of some particular communities and caste in India. Their studies intention is to see or develop the clusteral impact on particular section of people, mainly the poor. And in this paper we discuss the rural economic development in north east through a case study on Barpeta district on Assam. This is an important state of north east. Whose small households industries are back bone of their state gross domestic product (SGDP) and these industries are very much related with their cultural and custom.

\section{Case Study on Cane And Bamboo Cluster in BARPETA DISTRICT (ASSAM)}

The Barpeta Cane and Bamboo craft Cluster situated in the Raipur Village of Barpeta district. The district is $90 \mathrm{Km}$ from the state capita Assam surround by one international and 4 different district boarders. Anchalik Gram Unnayan Parishad (AGUP) under the SFURTI schemes of KVIC has developed this cluster by covering 5 villages i.e. Raipur, Bhaluki, Dhupguri, Joshihatigaon and Joshihatichar in the year 2008. Here the villagers are traditionally rich in cultural and households industries namely cane and bamboo products. AGUP intervene this cluster with an objective to provide new design inputs, provide access to new markets and strengthening the supply chain. The major turning point was to setting up CFC (Common Facility Center), provision for direct linkages with the foreign buyers and participation in the different exhibition, trade fair etc.

After the initiative taken by AGUP in Barpeta district, the result was that more than 650 nos. of artisans has directly engaged as a full time worker in cane and bamboo base industry. Their income also rises to about Rs.4, 500/- from the earlier Rs.700/- per month. At Raipur village a CFC, measuring $1300 \mathrm{Sq} . \mathrm{ft}$ has been introduces with new advance machineries for the benefits of entire cluster artisans. This has helped in increasing production and achieving level of international standard in design and other look. Besides this 
CFC, another 100 artisans were helped with toolkits for their own setup in the same village. To measures the quality control and improvement in designing, processing and treatment has been provided by IIT, Guwahati. Under market promotion assistance few exhibition has been organized at Guwahati and other parts of India. A show room has been established at Barpeta Road to facilitate regular sale of the Cane and bamboo products. Under capacity building programme awareness camp and capacity building training has organized to develop the cluster approach and motivate the artisans. To promote social security to the artisans an insurance scheme has been introduced among the artisans and identity cards were issued from DC Handcraft.

TABLE-III: THE VILlages AND TheIR SPECIALIZATION AND THE EMPLOYMENT STATUS

\begin{tabular}{|c|c|c|c|c|c|c|}
\hline \multirow[t]{2}{*}{$\begin{array}{l}\text { Name of } \\
\text { Blocks }\end{array}$} & \multirow[t]{2}{*}{$\begin{array}{c}\text { Name } \\
\text { of village }\end{array}$} & \multicolumn{3}{|c|}{ Community } & \multirow[t]{2}{*}{$\begin{array}{l}\text { House } \\
\text { holds }\end{array}$} & \multirow[t]{2}{*}{$\begin{array}{l}\text { No. of } \\
\text { Artisan }\end{array}$} \\
\hline & & $\mathrm{Sc}$ & $\mathrm{ST}$ & $\begin{array}{l}\text { Genera } \\
1\end{array}$ & & \\
\hline $\begin{array}{l}\text { Chakchak } \\
\text { a }\end{array}$ & Raipur & - & - & 2065 & 320 & 260 \\
\hline $\begin{array}{l}\text { Chakchak } \\
\text { a }\end{array}$ & Bhaluki & - & - & 2763 & 430 & 320 \\
\hline $\begin{array}{l}\text { Chakchak } \\
\text { a }\end{array}$ & $\begin{array}{l}\text { Joshihatig } \\
\text { aon }\end{array}$ & - & - & 1390 & 300 & 250 \\
\hline $\begin{array}{l}\text { Chakchak } \\
\text { a }\end{array}$ & $\begin{array}{l}\text { Charjoshi } \\
\text { hati }\end{array}$ & - & - & 400 & 105 & 50 \\
\hline $\begin{array}{l}\text { Chakchak } \\
\text { a }\end{array}$ & Dhupguri & 57 & 163 & 1694 & 500 & 65 \\
\hline Total & & 57 & 163 & 8412 & 1655 & 945 \\
\hline
\end{tabular}

Source: Barpeta Cane \& Bamboo Craft Cluster Annual Report (2010).

Taking into consideration the above table: (5), the Barpeta cane and bamboo craft cluster is covering 5 villages under the block of Chakchaka. The total numbers of households in these villages are 1655. Among the total households the ST, ST and general communities' people are 57, 163 and 8412 in Nos. The numbers artisans which are engaging as apart and full time basis in this bamboo crafts is about 945 .

TABLE-IV: ANNUAL PRoduction AND SALE of THE Cluster

\begin{tabular}{|c|r|r|r|r|}
\hline \multirow{2}{*}{ Items } & \multicolumn{2}{|c|}{$\begin{array}{c}\text { Production } \\
\text { (in Rs. Cr) }\end{array}$} & \multicolumn{2}{|c|}{$\begin{array}{c}\text { Sales } \\
\text { (in Rs. Cr) }\end{array}$} \\
\hline $\begin{array}{c}\text { Production } \\
\text { and sales of } \\
\text { furniture's and } \\
\text { other decorative } \\
\text { items }\end{array}$ & $2008-09$ & $2009-10$ & $2008-09$ & $2009-10$ \\
\cline { 2 - 5 } & 4.00 & 4.18 & 5.00 & 6.19 \\
\hline
\end{tabular}

Source: Barpeta Cane \& Bamboo Craft Cluster Annual Report (2010) and some contribution by the researcher himself.

The Table- 4, shows that the production of Barpeta cane and Bamboo craft cluster in the year 2008-09 was about 4.00 $\mathrm{Cr}$, which has increased by $4.18 \mathrm{Cr}$. in the year 2009-10. Again the sales of cluster products during in these two financial years increased to $6.19 \mathrm{Cr}$. from $5 \mathrm{Cr}$. in 2008-09.
The percentage of increasing production and sales during in these years was $.45 \%$ and $23.8 \%$ respectively.

TABLE- V: SOCIAL SECURITY REPORT FOR CLUSTER'S ARTISAN

\begin{tabular}{|c|c|}
\hline Items & Beneficiary (in Nos.) \\
\hline Insurance cover & 200 \\
\hline Health checkup camp & 2 \\
\hline Family cover for SHG formation & 45 \\
\hline Loan to the artisan & 76 \\
\hline
\end{tabular}

Source: Barpeta Cane \& Bamboo Craft Cluster Annual Report (2010)

For the social security of the cluster artisans, the Barpeta cane and Bamboo craft cluster have made the provision of insurance scheme, free health checkup camp, loan to the artisans etc. The numbers of insurance beneficiaries are 200 , in loan 76 in nos.

\section{CONCLUSION}

Cluster plays a very important role in an economy. It works as a vehicle for rural poverty alleviation, rural income generation and regional economic development. Many governments developed and developing has introduced cluster approach in their countries and different case studies shown that these approaches has positive contribution to their regional economic development and poverty alleviation programme. Therefore taking into consideration all the benefits of cluster approach of rural and regional economic development, NER can take the benefits of this approach for their economic development. This will bring a new life to the rural economy of North East. The various institutional framework and governmental policies can play a very important role in the field of cluster development.

\section{REFERENCES}

[1] A. J. Uddin. (2007), 'Industrialisation in Northeastern Region. Mittal Publication, New Delhi. ISBN-81-8324-186-7.

[2] Annual Report (2008), North Eastern Development Finance Corporation Limited. Guwahati (India).

[3] Annual report (2008), Apex Cluster Development Services Pvt. Ltd New Delhi.

[4] Annual report (2010), 'Foundation of MSME Cluster'. New Delhi.

[5] Barkley. L. D, Henry. S.M. (2005), 'Targeting Industry Cluster for Regional Economic Development: An Overview of the REDRL Approach. Regional Economic Development Research Laboratory Clemson University.

[6] Bhaskaran, P. Bala. 'A Frame-work for Cluster Initiatives in the Indian Context'. ICFAI Business School, Ahmedabad.

[7] Bisso, Ricardo. (2003), 'Cluster and Development Strategies: Reflections for Developing Country's SME policy'. www.lanic.utexas.edu/pyme/eng/publications/library/pdf/clusters.pdf

[8] Business Standard Report (2011), 'Benefit from MSME Development in North East'. New Delhi January 25.

[9] Carroll. C. M, Reid. N. (2004), 'Cluster Base Economic Development: A comprehensive Strategy to Secure NW Ohio's Economic Future, Center for Policy Analysis and Public Service.

[10] Chawii. Lian. (2007), 'Natural Resource Based Income and Livelihood Improvement Initiatives in North East' www.mdoner.gov.in/.../14NaturalResourceIncome7872117900.pdf

[11] Cluster Development and Poverty Alleviation: Policy Suggestions. Foundation for MSME Clusters. www.msmefoundation.org/folder/Publication/49.pdf.

[12] Coppard David. (2001), 'The Rural Non-Firm Economy in India: A Review of the Literature'. Natural resource Institute. www.citeseerx.ist.psu.edu/viewdoc/download?doi=10.1.1.110 
[13] Das, K. (1998), 'Collective Dynamism and Firm Strategy: Study of an Indian Industrial Cluster'. International Journal of Entrepreneurship and Regional Development, Routledge Vol.10:pp. 33-49.

[14] Foundation for MSME Clusters, New Delhi (2007), 'Policy and Status Paper on Cluster Development in India'.

[15] Foundation for MSME Clusters, New Delhi (2008), 'Cluster Development and Poverty Alleviation.

[16] Henry.S.M, Barkely. D. (1997), 'Industry Cluster in the TVA Region: Do They Affect Development of Rural Areas? Contract Paper 98-9. www.search.uky.edu/Ag/AgEcon/pubs/tva/staff/henry98-9.pdf

[17] 'India: Profile of North East' (2011). Italian Trade Commission, Italia. www.www.ice.gov.it/../india/.../India\%20Profile\%20of\%20the $\% 20 \mathrm{~N}$ orth\%20East $\% 202011$.pdf

[18] Industrial Policy of Assam (2008), 'Preamble: the New Paradigm for Growth and Industrial Investment in Assam'. Government of Assam.

[19] Isbasoiu. M.G. (2007), 'Industrial Cluster and Regional Development. The Case of Timisoara and Montebelluna. ERIK Network Conference, Brussels.

[20] Jenner, V.G Reza, Md. Selim. 'Agarbattis: A Sustainable Bamboo Cluster based Rural Enterprise Development in Northeast Region of India through $\quad \mathrm{P} 4 \quad$ Approach'. www.www.tripurabamboo.com/Reports/Agarbatti ArticleAr.pdf

[21] John. E. (1999), 'Industry Clusters an Economic Development Strategy for Minnesota Preliminary Report'. Humphrey Institute of Public Affairs and University of Minnesota Extension Service. www.hhh.umn.edu/.../economic_development/.../econdev_strategy_m n_industry_cluster.pdf

[22] Joseph. C. (2006), 'Making Sense of Clusters: Regional Competitiveness and Economic Development'. A Decision Paper Prepared for the, 'the Brooking Institute of Metropolitan Policy Programme. www.brookings.edu/metro/pubs/20060313 clusters.pdf

[23] Mishra. S.K. (2007), 'Recent Trend of Village and Small Enterprise Sector Exploring and Exploiting its Opportunities in the North Eastern Region of India touching upon its Profile and Barriers'. Northeastern hill university, Shillong (Meghalaya)

[24] MSME Statistical Report (2001-02), New Delhi.

[25] MSME (2009-10). Annual Report, New Delhi.

[26] Munnich. (1999), 'Industrial cluster: An Economic Development Strategy for Minnesota'. Preliminary report University of Minnesota Extension Service.

[27] Marian, George. (MPRA 2006), 'Industrial Clusters and Regional Development: The Case of Timisoara and Montebelluna'. Isbasoiu, University of Urbino 'Carlo Bo'.

[28] Montana. P. J, Nenide. B. (2008), 'The Evaluation of Region Industry Clusters and Their Implications for Sustainable Economic development. Economic Development Quarterly, vol-22.

[29] Motorola India Research Labs (2007), 'Collaboration on Indian SME Clusters': A Case Study by Shantanu Biswas, Soumya Roy, and Sarita Seshagiri. www.ebusiness.tc.msu.edu/cct2007/files/shantanu.pdf

[30] Myrdal, G. (1957), 'Economic Theory and Underdevelopment Regions'. London: Dnekworth.
[31] Nadvi. K. (2010), 'Cluster, Poverty and Rural Off-Grid Electrification. OASYS- South Asia Project. Working paper-5.

[32] 'North East State'. Lonely Planet Publication 591 www.lonelyplanet.com/shop.../india-12-northeast-states-preview.pdf

[33] Nsimbi, Phambuka Catherine. (2008), 'Creating Competitive Advantage in Developing Countries through Business Cluster: A Literature Review'. African Journal of Business Management. Vol.2 (7), pp. 125-130, July 2008.

[34] Planning Commission, Government of India (New Delhi), 'Report on Rural Cluster Development: A Case Study'. Society for Economic and Social Transition.

[35] Porter, M. (1998), 'Cluster and the New Economics of Competition' Harvard Business Review, Vol. 76, issue.6, pp.77-90.

[36] Porter, M.E. (2000), 'Location, Competition \& Economic Development: Local Cluster in a Global Economy'. Economic Development (Quarterly), Vol. 14, p.15.

[37] Prajapati. K. (2008) 'Strategic Issues in SME's. 11th Annual Convention of the Strategic Management Forum, IIT Kanpur, Pp.1-12, May 8-10.

[38] Pradhan. P.R. (2011), 'Econometric Approach Between Human Development and Poverty in North Eastern Region of India'. Information Management and Business Review. Vol-2.pp-26-37.

[39] Roy. B.U, Das. G. (2007), 'Dimension of Rural Development in NorthEast India'. Akansha Publication House, New Delhi. ISBN81-87606-23-1.

[40] Rosenfeld. S.A. (1995), 'Industrial Strength Strategies: Regional Business Cluster and Public Policy'. Washington, D C. The Aspen Institute.

[41] Rosenfield. S. A. (1997), 'Bringing Business Clusters into the mainstream of Economic Development'. European Planning Studies, Vol. 5, issue.1: pp. 3-23.

[42] Russo, Fabio. (1999), 'Strengthening Indian SME Clusters: UNIDO'S Experience'. A Case Study, Project: US/GLO/95/144.

[43] Schmitz, (1995), 'Collective Efficiency: Growth Path for Small Scale Industry'. Journal of Development Studies, Routledge, Vol. 31, issue.4: pp.529-566.

[44] Singh. K. (2009), 'Rural Development Principles, Policies and Management'. SEGE publication India Pvt Ltd, New Delhi.

[45] Small Scale Industry (2002-03). Annual report.

[46] Sonobe, T., \& Otsuka, K. (2006, b), 'Cluster-Based Industrial Development: An East Asian Mode'. Hampshire, UK: Palgrave Macmillan. [48]Sukumaram. M.K, Mathew. P. M. (2000), 'Poverty Alleviation Programme and Structural Changes in the Rural Economy'. Institute of Small Enterprises and Development

[47] The Challenge of Employment in India: An Informal Economy Perspective (2009). Vol-1. National Commission for Enterprises in the Unorganised Sector.

[48] UNIDO (2004), 'Industrial Cluster and Poverty Reduction: Towards a methodology for Poverty and Social Impact Assessment of Cluster Development Initiatives'. Vienna 